\title{
Potres u Đakovštini 1964. godine - stradanje i tijek obnove katedrale svetoga Petra u Đakovu
}

\author{
SLAĐANA JOSIPOVIĆ BATOREK \\ Filozofski fakultet Osijek \\ Osijek, Hrvatska \\ sjosipovic@ffos.hr
}

U radu se na temelju dostupnoga arhivskoga gradiva i onodobnoga tiska govori o posljedicama potresa koji je 1964. pogodio Slavoniju i prouzročio veliku materijalnu štetu. U uvodnom dijelu daje se kratki prikaz štete nastale na području kotara Osijek, tj. općine Đakovo, te osnovni podaci o štetama na vjerskim objektima. Središnji dio rada posvećen je analizi posljedica potresa i procesu obnove katedrale svetoga Petra u Đakovu, koja je tek bila započela s popravljanjem oštećenja nastalih još u Drugom svjetskom ratu. Glavnu riječ tijekom obnove imao je Stolni kaptol i u tu svrhu osnovan Odbor za obnovu katedrale, ali i tadašnji biskup Stjepan Bäuerlein, koji je brojnim predstavkama upućenim državnim vlastima nastojao ishoditi novčanu pomoć za potrebe obnove. U tom je smislu cijeli proces obnove katedrale zanimljivo pratiti i u kontekstu odnosa između Katoličke crkve u Jugoslaviji i komunističkih vlasti, koji su šezdesetih godina bili u znaku popuštanja napetosti.

Ključne riječi: potres; Đakovština; 1964.; Đakovačka i Srijemska biskupija; katedrala svetoga Petra u Đakovu; Odbor za obnovu katedrale; biskup Stjepan Bäuerlein

\section{Uvod}

Osim velikih političkih, gospodarskih i društvenih previranja, šezdesete godine XX. stoljeća u Jugoslaviji obilježili su i snažni prirodni potresi, koji su za posljedicu imali znatne ljudske gubitke i iznimno veliku materijalnu štetu. Prvi snažniji potresi toga razdoblja pogodili su Makarsko primorje. Radilo se o seriji potresa u siječnju 1962., od kojih su najrazorniji bili onaj 7. siječnja (jakosti 5,9 po Richteru) i 11. siječnja (jakosti 6,1 po Richteru). Poginulo je dvoje ljudi, srušene su brojne starije kuće u selima pod Biokovom, a stanovnici sela poslije su uglavnom napustili ta mjesta i izgradili kuće uz more. ${ }^{1}$ Godinu i pol kasnije, 26. srpnja 1963., potres jačine 6,9 stupnjeva po Richteru uništio je

1 HRSTIĆ, „Zbivanja na Makarskom primorju tijekom i nakon potresa 1962. godine”, 280-281; MUSTAPIĆ, KARAJIĆ, „Prirodne katastrofe kao čimbenici modernizacije hrvatskog društva: primjer potresa 1962. godine na Makarskom primorju”, 309-310. 
80\% Skopja, glavnoga grada Socijalističke Republike Makedonije. Poginulo je preko 1000 ljudi, više od 3000 je ozlijeđeno, a između 120000 i 200000 ostalo je bez doma. Dan potresa ubrzo se počeo obilježavati kao „Dan solidarnosti” u Jugoslaviji jer je grad obnovljen sredstvima iz cijele države. Materijalnim sredstvima i angažmanom svjetski poznatoga arhitekta Kenza Tangea u obnovi grada pomažu Ujedinjeni narodi, a pomoć u vidu novca, medicinskih, inženjerskih i građevinskih timova te namirnica ponudilo je 78 država. Banja Luka je 27. listopada 1969. teško oštećena u potresu jačine 6 stupnjeva po Richteru. Poginulo je 15 ljudi, preko 1000 je ozlijeđeno, a materijalne štete bile su goleme. Potpuno je uništeno 86000 stanova, a velika oštećenja pretrpjeli su školski (266), kulturni (146), zdravstveni (133), društveni i objekti javne uprave administracije (152). ${ }^{2}$ Dana 13 . travnja 1964 . potres jačine 5,6 po Richteru pogodio je i Slavoniju. Epicentar je bio u okolici Slavonskoga Broda, zbog čega su najveće štete pretrpjele tadašnje općine Slavonski Brod, Đakovo, Slavonska Požega, Našice i Vukovar. U nastavku rada više će riječi biti o posljedicama potresa na području tadašnje općine Đakovo te štetama nastalim na vjerskim objektima, o čemu će se govoriti u uvodnom dijelu, a središnji dio rada bit će posvećen analizi posljedica potresa i procesu obnove katedrale svetoga Petra u Đakovu. Pritom je najvećim dijelom korišteno arhivsko gradivo Nadbiskupijskoga arhiva u Đakovu, u kojemu se, kao dio fonda Biskupske kancelarije, nalaze brojni dokumenti i podaci o potresu, njegovim posljedicama, kao i o angažmanu biskupa Stjepana Bäuerleina ${ }^{3}$ i Stolnoga kaptola u obnovi katedrale. Osim toga korišteni su i određeni fondovi Državnoga arhiva u Osijeku, objavljeni arhivski izvori i onodobni tisak (Đakovački gospodarski list i Glas Slavonije).

\footnotetext{
2 „Potres u Skoplju 1963.”; „Zemljotresi u Banjaluci”.

3 Stjepan Bäuerlein (Babina Greda, 1905. - Đakovo, 1973.), đakovački i srijemski biskup. Bogosloviju završio u Đakovu, diplomirao teologiju 1937. u Zagrebu. Od 1929. svećenik u raznim mjestima Đakovačke biskupije. Đakovačkim biskupom imenovan 1951. kao pomoćnik tadašnjega biskupa Antuna Akšamovića. Nakon smrti biskupa Akšamovića 1959. postaje rezidencijalnim biskupom Đakovačke i Srijemske biskupije. Kao biskup djelovao je izrazito pastoralno, a na Visokoj bogoslovnoj školi u Đakovu osnovao Katehetski institut. U biskupskom dvoru u Đakovu osnovao Dijecezanski muzej sakralne umjetnosti. Objavljivao je radove iz područja katehetike, crkvene povijesti i odgoja. Za razliku od svojega prethodnika Akšamovića, imao je vrlo negativan odnos prema komunističkim vlastima te je izbjegavao bilo kakvu suradnju ili kontakte s predstavnicima vlasti, što će se postupno promijeniti tek u drugoj polovini 60-ih godina. Više vidi u: JOSIPOVIĆ BATOREK, Sukob i(li) suradnja.
} 


\section{Posljedice potresa i materijalna šteta na vjerskim objektima na području općine Đakovo ${ }^{4}$}

Dana 13. travnja 1964. u 9:30 istok Socijalističke Republike Hrvatske zatresao je potres jakosti 5,6 po Richteru. ${ }^{5}$ Budući da je epicentar bio u neposrednoj okolici Slavonskoga Broda, potres je prouzročio velike materijalne štete na širem području kotara Osijek, koji je u tom razdoblju obuhvaćao općine Beli Manastir, Donji Miholjac, Đakovo, Našice, Nova Gradiška, Orahovica, Osijek, Podravska Slatina, Slavonska Požega, Slavonski Brod, Valpovo, Vinkovci, Vukovar i Županja. ${ }^{6}$ Nastale materijalne štete velikim se dijelom mogu pripisati činjenici da su se tek od 1964., nakon razornoga potresa u Skopju, počeli razvijati i primjenjivati seizmološki propisi kao jedan od uvjeta gradnje. Osobito velike štete nastale su na području općina Slavonski Brod, Đakovo, Slavonska Požega, Našice i Vukovar. Prvi novinski izvještaji o potresu koji je pogodio Slavoniju nisu ni približno mogli prikazati prave razmjere štete, čija će procjena trajati tijekom sljedećih mjeseci. Dan nakon potresa Glas Slavonije donosi prve vijesti s pogođenoga područja, iz kojih saznajemo da je potres na području Đakova odnio i jedan ljudski život. U nastavku se u kratkim crtama daje sažet pregled za nekoliko mjesta s podacima o ozlijeđenim osobama i materijalnoj šteti, iz čega se u prvi mah nije moglo zaključiti da je potres izazvao veća stradanja. ${ }^{7}$ Već trećega dana izvještaji su govorili o materijalnoj šteti na području Slavonije koja se približavala iznosu od 9 milijardi dinara. ${ }^{8}$

Tijekom idućih dana stradalo područje posjetili su brojni partijski dužnosnici, kao i predsjednik Socijalističke Federativne Republike Jugoslavije (SFRJ) Josip Broz Tito osobno sa suprugom Jovankom, koji su na brodsko područje došli 18. travnja. Tom prilikom s Titom su doputovali i sekretar Centralnoga komiteta Saveza komunista Hrvatske Vladimir Bakarić, predsjednik Sabora Socijalističke Republike Hrvatske Ivan Krajačić i glavni Titov tajnik Bogdan Crnobrnja. Tita i njegovu pratnju dočekali su predsjednik Kotarske skupštine Osijek Gojko Prodanić i predsjednik Općinske skupštine Slavonski Brod Stje-

$4 \quad$ U predmetnom razdoblju općina Đakovo bila je sastavni dio kotara Osijek, a u njezino su područje ulazila sljedeća mjesta: Borojevci, Borovik, Bračevci, Breznica Đakovačka, Bučje Gorjansko, Budrovci, Čenkovo, Dragotin, Drenje, Đakovo, Đurđanci, Forkuševci, Gašinci, Gorjani, Hrkanovci Đakovački, Ivanovci Gorjanski, Josipovac Punitovački, Jurjevac Punitovački, Kešinci, Kondrić, Koritna, Krndija, Kućanci Đakovački, Kuševac, Lapovci, Lipovac Hrastinski, Levanjska Varoš, Majar, Malo Nabrđe, Mandićevac, Milinac, Mrzović, Musić, Ovčara, Paljevina, Paučje, Piškorevci, Podgorje Bračevačko, Potnjani, Preslatinci, Pridvorje, Punitovci, Ratkov Dol, Satnica Đakovačka, Semeljci, Selci Đakovački, Slatinik Drenjski, Slobodna Vlast, Svetoblažje, Široko Polje, Tomašanci, Trnava, Veliko Nabrđe, Viškovci, Vrbica, Vučevci. BOŽIĆ-DRLJAČA, „Pregled uprave na području Državnog arhiva u Osijeku 1947. - 1992.”, 344.

5 Detaljnije o potresu 1964. vidi u: JOSIPOVIĆ BATOREK, „Potres u Đakovštini 1964. godine", 179-196.

6 BOŽIĆ-DRLJAČA, „Pregled uprave na području Državnog arhiva u Osijeku 1947. 1992.", 343-345.

„Potres na širem području”, Glas Slavonije (Osijek), 14. 4. 1964., 1.

„Šteta u Slavoniji od potresa blizu 9 milijardi”, Glas Slavonije, 17. 4. 1964., 1. 
pan Rajković, a prisutni su bili i predsjednik i potpredsjednik Saveznoga izvršnog vijeća Petar Stambolić i Veljko Zeković, savezni ministar obrane Ivan Gošnjak, potpredsjednik Savezne skupštine Zvonko Brkić, predsjednik Glavnoga odbora Socijalističkoga saveza radnog naroda Antun Biber, predsjednik Odbora za društveni plan i financije Slavko Komar, pomoćnik saveznoga ministra za vanjske poslove Ivo Sarajčić i glavni sekretar Kotarskoga komiteta Saveza komunista Osijek Mirko Lacković. Istoga dana tijekom poslijepodneva dio partijskih dužnosnika obišao je i pogođena mjesta na području općina Slavonska Požega i Đakovo. ${ }^{9}$

Da bi se što prije prikupili podaci o veličini nastale štete, neposredno nakon potresa osnovan je Kotarski štab za zaštitu od elementarnih nepogoda, koji je služio kao izravna veza s pogođenim općinskim centrima i čiji je glavni zadatak bio procjena štete. Desetak dana nakon potresa, točnije 24. travnja, Štab je iznio i prve podatke o razmjerima štete na području kotara Osijek, koja je iznosila nešto više od 17 milijardi dinara. ${ }^{10} \mathrm{U}$ pogledu ljudskih žrtava, u izvješću Štaba navedena su dva smrtna slučaja, i to na području Slavonskoga Broda i Đakova. U Đakovu je uslijed stampeda u Osnovnoj školi Ivana Gorana Kovačića zbog urušavanja stubišta smrtno stradala trinaestogodišnja učenica 5. razreda Milka Tokić iz Širokoga Polja, a okolnosti pogibije druge žrtve nisu poznate. Naime, u ondašnjem se tisku u vijestima o stradanjima na području Slavonskoga Broda objavljenim tijekom travnja 1964. nigdje ne spominje da je bilo smrtnih slučajeva prouzrokovanih potresom. I na internetskim stranicama na kojima danas možemo pronaći podatke o potresu u Slavonskom Brodu izričito se navodi da nije bilo ljudskih žrtava, stoga bi podatak iznesen u izvješću Štaba trebalo gledati s određenom rezervom. ${ }^{11}$

Tri dana kasnije, 27. travnja, na sjednici Skupštine kotara Osijek, na kojoj se raspravljalo o spomenutom izvješću Štaba, donesena je i odluka o osnivanju Fonda za obnovu zemljotresom postradalih krajeva na području kotara Osijek te je imenovan Upravni odbor Fonda na čelu s predsjednikom Skupštine kotara Osijek Gojkom Prodanićem. ${ }^{12}$

\footnotetext{
9 „Akciji obnove treba dati općejugoslavenski karakter”, Glas Slavonije, 19. 4. 1964., 1.

10 Prema srednjem tečaju Narodne banke Jugoslavije za 1964. godinu (1:300), iznos nastale štete izražen u američkim dolarima bio je nešto više od 56,6 milijuna dolara. Prema inflacijskom kalkulatoru, navedena vrijednost u dolarima 1964. imala je istu kupovnu moć kao i 477,1 milijuna dolara 2021. godine. Vidi: Kunalipa - Hrvatski numizmatički portal.

11 HR-DAOS-64-SKO, kut. 1393, „Osnivanje fonda, izvještaji i zapisnici o postradalim objektima na području kotara Osijek 1964./1965.” (dalje: „Osnivanje fonda...”), Podaci o elementarnoj šteti od zemljotresa - Informacija, 25. 4. 1964.; „Učenica Milica Tokić žrtva potresa”, Glas Slavonije, 14. 4. 1964., 1; „Snažan potres u većem dijelu zemlje”, Đakovački gospodarski list (Đakovo), 17. 4. 1964., 1; „Tragična bilanca 13. travnja”, Đakovački gospodarski list, 24. 4. 1964., 1; „Đakovo, Dilj gora i Beli Manastir mogući epicentri jakih potresa”, Glas Slavonije, mrežno izdanje, 6. 11. 2010., pristup ostvaren 30. 6. 2021., http://www.glas-slavonije.hr/124004/1/Djakovo-Dilj-gora-i-Beli-Manastir-moguci-epicentri-jakih-potresa.

12 HR-DAOS-64-SKO, kut. 1393, „Osnivanje fonda...”, 02-6443/1-64, 27. travnja 1964., 026444/1-64, 27. travnja 1964.; „17 milijardi dinara. Donesena odluka o formiranju fonda za obnovu potresom postradalih krajeva na području kotara Osijek", Glas Slavonije, 28. 4. 1964., 1.
} 
I u slučaju općine Đakovo prve procjene štete objavljene dva dana nakon potresa bile su daleko od stvarnosti i kretale su se oko iznosa od 200 milijuna dinara. ${ }^{13}$ Samo tri dana poslije vijesti su govorile o materijalnoj šteti u iznosu od oko 2 milijarde dinara, a do kraja travnja šteta je premašila iznos od $3 \mathrm{mi}-$ lijarde dinara. ${ }^{14}$ Prema podacima komisija koje su obilazile područje općine Đakovo, potres je najveće štete prouzročio u zapadnom dijelu Đakovštine, $\mathrm{u}$ selima Musić, Lapovci, Hrkanovci, Ovčara, Paučje, Slobodna Vlast i Levanjska Varoš te u Vučevcima na istoku i Ivanovcima na zapadu Đakovštine. Veći broj ljudskih žrtava, prema mišljenju stručnjaka, izbjegnut je zahvaljujući činjenici da su se ljudi u to vrijeme najviše nalazili na radu u poljima, a samo manji broj potres je zatekao u zgradama. Odmah drugoga dana nakon potresa jedinice Jugoslavenske narodne armije u stradalim su selima postavile 100 šatora za smještaj najugroženijih, a idućih se dana broj šatora udvostručio. $\mathrm{Na}$ pogođeno područje također je upućena pomoć u hrani i odjeći. ${ }^{15}$

Radi prikupljanja podataka o razmjerima štete na vjerskim objektima na području Đakovačke i Srijemske biskupije biskup Bäuerlein zatražio je u Biskupskoj okružnici od 17. travnja 1964. od svih župnih ureda izvještaj o potresu i njegovim posljedicama, i to u obliku upitnoga arka koji je sadržavao 13 pitanja. Na temelju prikupljenih podataka koji su idućih tjedana stizali iz pogođenih župa utvrđeno je da šteta na vjerskim objektima na području Biskupije iznosi preko 300 milijuna dinara. Nadalje, posebna općinska komisija koja je obilazila vjerske objekte utvrdila je da šteta samo na području općine Đakovo iznosi oko 90 milijuna, a u gradu Đakovu 26 milijuna dinara. ${ }^{16} \mathrm{~S}$ obzirom na visinu iznosa, đakovački biskup Bäuerlein uputio je 13 . svibnja molbe općinskoj i republičkoj Komisiji za vjerska pitanja ističući da oštećene vjerske zgrade na području općine Đakovo nemaju vlastitih sredstava iz kojih bi financirale obnovu te da im se stoga dodijeli što je moguće veća pomoć u novcu i građevnom materijalu i omogući podizanje kredita pod istim uvjetima koji vrijede za građane čije su kuće stradale u potresu. Istoga je dana Bäuerlein uputio molbe i svim biskupijama i nadbiskupijama u Jugoslaviji za slanje novčane pomoći Đakovačkoj i Srijemskoj biskupiji. ${ }^{17}$ Tijekom idućih tjedana i mjeseci, što je vidljivo iz arhivskih dokumenata, Đakovačkoj biskupiji upućeni su brojni izrazi sućuti i novčane donacije i iz župa i biskupija s područja SFRJ i iz inozemstva. Osim dobrovoljnih priloga vjernika, svećenika i biskupa, Biskupskom ordinarijatu pomoć je stigla i u obliku kredita u iznosu od 2 milijuna dinara koji je odobrio Općinski fond

13 „Šteta u Đakovštini veća od 200 milijuna”, Glas Slavonije, 15. 4. 1964., 2.

14 „U Đakovštini srušeno 556 stambenih objekata”, Glas Slavonije, 18. 4. 1964., 2; „Otklanjaju se posljedice”, Glas Slavonije, 21. 4. 1964., 2; „Tragična bilanca 13. travnja”, Đakovački gospodarski list, 24. 4. 1964., 1; „Razmotren izvještaj o posljedicama potresa”, Đakovački gospodarski list, 8. 5. 1964., 1.

15 „U Đakovštini srušeno 556 stambenih objekata”, Glas Slavonije, 18. 4. 1964., 2; „Tragična bilanca 13. travnja", Đakovački gospodarski list, 24. 4. 1964., 1.

16 NAĐ-BK, 900/1964, 17. travnja 1964., 27. travnja 1964.

17 NAĐ-BK, 900/1964, 17. travnja 1964. 
za izgradnju u Đakovu i 3 milijuna dinara donacije Savezne komisije za vjerska pitanja u Beogradu. ${ }^{18}$

\section{Obnova đakovačke katedrale nakon potresa 1964. godine}

Gotovo polovica iznosa štete na vjerskim objektima u Đakovu odnosila se na štetu nastalu na katedrali svetoga Petra. ${ }^{19}$ Potres je srušio $500 \mathrm{~kg}$ težak kameni ljiljan na vrhu sjevernoga tornja, koji je probio krovište, razbio i uništio mehanizam sata na tornjevima. Porušeno je bilo i nekoliko ukrasnih tornjeva na zapadnom dijelu katedrale te je oštećen dobar dio tek popravljenoga krovišta. U unutrašnjosti katedrale dodatno su napukla oštećenja nastala u Drugom svjetskom ratu, pojavile su se i nove pukotine na zidovima i svodu, a na više je mjesta otpala dekorativna žbuka. Slike i oltari su ostali neoštećeni, osim što je s baldahina glavnoga oltara pao i razbio se jedan od četiri kipa anđela. Ukupna šteta na katedrali procijenjena je na 12 milijuna dinara. ${ }^{20}$ Potres je dodatno otežao i na određeno vrijeme zaustavio započetu obnovu katedrale od štete nastale još u Drugom svjetskom ratu. Naime, tijekom Travanjskoga rata i povlačenja jugoslavenske vojske 1941., a zatim i u završnim ratnim operacijama 1945., katedrala je zadobila veća oštećenja, ponajprije na fasadi i krovištu. ${ }^{21} \mathrm{Od}$ tih je oštećenja provizorno popravljeno krovište, nadomještena su razbijena stakla u rozetama te je restaurirana freska Kristova krštenja. Ostalim se popravcima zbog pomanjkanja financijskih sredstava nije pristupilo te se stanje s vremenom pogoršavalo. Nakon petnaestogodišnje pauze nastavak radova na obnovi katedrale inicirao je biskup Bäuerlein, koji je krajem 1959. od Stolnoga kaptola zatražio pomoć i posredovanje u prikupljanju sredstava potrebnih za nužne radove. U svojem dopisu Bäuerlein ističe da su oštećenja na katedrali, osim što „nagrdjuju njezinu ljepotu”, pod utjecajem vremena iz dana u dan sve veća i opasnija te apelira na Kaptol da na svojim sjednicama uzmu u razmatranje to "goruće pitanje” i pokušaju pronaći način za osiguranje sredstava potrebnih za najnužnije popravke. U tu je svrhu krajem 1960. izrađen i stručni elaborat o stanju stolne crkve s prijedlozima za popravak. Prema elaboratu, predloženo je da se radovi podijele u tri grupe: hitni zahvati (popravak pokrova lađa, tornjeva, kupole i prigradnje, uređenje odvodne limarije, kontrola i popravak drenažnoga sustava), nužni zahvati (popravak oštećenja na vanjskim zidovima te na svodu glavne lađe i sjeverne apside) i ko-

18 NAĐ-BK, 900/1964, 17. kolovoza 1964., 1152/1964, 3. lipnja 1964., 935/1965, 20. travnja 1965.

19 Đakovačka katedrala sv. Petra najveća je sakralna novogradnja hrvatskoga historicizma i jedna od najvažnijih sakralnih građevina Srednje Europe XIX. stoljeća. Izgrađena je na inicijativu đakovačkoga biskupa Josipa Jurja Strossmayera, a gradnja je trajala od 1866. do 1882., kad je i posvećena. Više vidi u: DAMJANOVIĆ, Đakovačka katedrala.

20 NAĐ-BK, 900/1964, Okružnice i obavijesti Biskupskog ordinarijata u Đakovu, 17. travnja 1964., 900/1964, 27. travnja 1964.; „Potres oštetio katedralu”, Đakovački gospodarski list, 30. 4. 1964., 4.

${ }^{21}$ DAMJANOVIĆ, „Đakovačka katedrala”, 616-617. 
načni radovi (saniranje vlažnih zidova, klesarski radovi, restauriranje fresaka te uređenje užega ambijenta objekta). Tijekom 1961. i 1962. pristupilo se radovima iz skupine „hitni zahvati”, no zbog nepredviđenih troškova pribavljena sredstva nisu bila dostatna ni za popravak krovišta, pa je obnova obustavljena i dovršena tek krajem 1963. godine. Radove iz druge i treće kategorije, koji su bili planirani za 1964., zaustavio je potres. ${ }^{22}$

Radi lakšega prikupljanja podataka o potresu i njegovim posljedicama na području Biskupije, Dijecezansko administrativno vijeće donijelo je odluku o osnivanju odbora čiji je zadatak bio davanje sugestija i uputa za obnovu objekata, organiziranje i prikupljanje dobrovoljnih priloga te njihovo razdjeljivanje najteže pogođenim župama. Ujedno je osnovan Odbor za obnovu katedrale, sastavljen od članova Stolnoga kaptola, na čelu s velikim prepoštom Josipom Sokolom i s još tri člana - Rudolfom Švererom, Ivanom Rogićem i Ilijom Anakovićem. ${ }^{23}$

Članovi Odbora za obnovu katedrale, izuzev Rogića, sastali su se 30. travnja 1964. s tajnikom Općinske komisije za vjerska pitanja Stjepanom Češnikom, prilikom čega im je prenesena informacija o odobrenju kredita u iznosu od 1,7 milijuna dinara od Fonda za unapređenje kulturnih djelatnosti za obnovu fasade katedrale. Kanonici su tijekom razgovora istaknuli da se, unatoč velikom obimu posla, nadaju da će svi radovi na katedrali biti gotovi do 1966. za kad se pripremala velika proslava povodom 100. obljetnice početka gradnje, te da će im za ispunjavanje toga cilja biti neophodna i pomoć države. U tom kontekstu Šverer je spomenuo da su nekoliko dana prije dobili i rješenje Saveznoga sekretarijata za financije u Beogradu kojim se od poreza oslobađaju donacije iz inozemstva u iznosu do 10.000 dolara. $^{24}$

Molbu za pomoć u obliku novčanih donacija za obnovu katedrale biskup Bäuerlein osim biskupijama i nadbiskupijama u Jugoslaviji uputio je i Međunarodnom Caritasu u Rimu. Tajnik Caritasa Karl Bayer savjetovao je Bäuerleinu da radi lakšega prikupljanja donacija iz inozemstva postupi isto kao splitski biskup prilikom potresa u Makarskoj 1962., tj. da kod Narodne banke otvore devizni žiro račun preko kojega bi primali pomoć. U skladu s tom preporukom predstavnik Biskupskoga ordinarijata u Đakovu obratio se Narodnoj banci u Osijeku, gdje je dobio informaciju da odobrenje za otvaranje deviznoga žiro računa daje isključivo Savezni sekretarijat za financije u Beogradu. Stoga je Bäuerlein 3. lipnja 1964. uputio molbu tome ministarstvu, tražeći da se osim otvaranja deviznoga računa odobri i korištenje popusta pri kupovini robe i materijala. Nadalje je istaknuo da se nada pozitivnom odgovoru „jer se radi o obnovi doista velikog i lijepog kulturno-historiskog spomenika koji je teško oštećen kako za vrijeme rata, tako i sada ponovno potresom". Iz dostupnoga arhivskoga gradiva nije mi poznat odgovor i konačno

22 NAĐ-BK, 300/1965, 1511/1959, 400/1963, 2350/1963.

23 NAĐ-BK, 901/1964, 16. svibnja 1964.; ĆURIĆ, Križni put u Strossmayerovoj katedrali, 6.

24 AKMADŽA, Crkva i država, sv. III: 1961. - 1964., 306; NAĐ-BK, 1152/1964, 3. lipnja 1964. 
rješenje ministarstva, no molba je najvjerojatnije pozitivno riješena budući da su tijekom 1964. Biskupskom ordinarijatu u Đakovu pristizale i novčane donacije iz inozemstva, koje su najvjerojatnije uplaćivane na žiro račun. ${ }^{25}$

Zbog složenosti poslova i višemilijunskoga iznosa potrebnog za njihovu realizaciju, do kraja 1964. i u prvih devet mjeseci 1965. nije se pristupilo izvođenju većih građevinskih zahvata na katedrali. Tijekom toga razdoblja naglasak je bio na prikupljanju dostatnih novčanih sredstava i izradi plana obnove koja je trebala započeti tijekom 1965. godine. O svemu tome raspravljalo se i na sjednici Odbora za obnovu katedrale 18. siječnja 1965. Na njoj je zaključeno da će poslove obnove oštećenih zidova izvoditi ekipa lokalnoga zidara Antuna Vuksanovića i klesarski majstori đakovačkoga građevinskog poduzeća „Rad”, pod nadzorom graditelja Ive Damjanovića. Također su planirani radovi u unutrašnjosti katedrale radi otklanjanja vlage, obnova fasade, za koju je bilo potrebno pribaviti građevinsku skelu, nabava novoga postolja za veliko zvono i novoga sata na tornjevima jer je stari uništen u potresu. ${ }^{26}$

Predstavnici Odbora za obnovu katedrale upoznali su s planovima radova i članove Općinske komisije za vjerska pitanja na sastanku održanom 8. veljače 1965. Tom je prilikom kanonik Josip Sokol izvijestio prisutne članove Komisije da su obavljene sve pripreme za radove koji trebaju uslijediti, no da još uvijek nemaju dovoljno novčanih sredstava, zbog čega su se ponovno morali obratiti državnim institucijama za pomoć, te da očekuju i određenu pomoć iz inozemstva. Istaknuo je da je postavljanje sata planirano u završnoj fazi radova kako bi ostao neoštećen te da se o njegovoj nabavci pregovara s proizvođačem satova u Ulmu. Također je spomenuo da na molbe za novčanu pomoć upućene Izvršnom vijeću Sabora i Republičkom sekretarijatu za kulturu još uvijek nisu dobili nikakav odgovor. U raspravu se nakon toga uključio član Komisije Mićo Cvjetičanin rekavši da su dobili informacije da je Biskupski ordinarijat u Klagenfurtu u vrijeme prikupljanja pomoći za Đakovačku biskupiju, a na dopis biskupa iz Rima, tiskao letak i članak u svojem službenom glasilu u kojem se govori da država nakon potresa nije pružila nikakvu pomoć Katoličkoj crkvi. Upitavši jesu li upoznati s tim i kako bi objasnili takav postupak, Cvjetičanin dodaje: „Naime mislim da Vam je poznato, da smo Vam do tog vremena u 1965. g. sa raznih strana bili pružili pomoći i kredit u visini od 4,7 miliona dinara." Kanonik Ilija Anaković odgovorio je da prvi put čuje za taj slučaj, da je uvjeren da biskup Bäuerlein sigurno nije poslao dopis takva sadržaja ,jer je on naročito oprezan i pazi na svoje istupe” i da je najvjerojatnije riječ o samostalnoj inicijativi Ordinarijata u Klagenfurtu. Nadalje, tajnik Komisije Češnik ističe da bi bilo potrebno istinito informirati javnost te u Klagenfurt uputiti dopis u kojem bi se demantirale njihove tvrdnje. Osim toga predlaže da se u Vjesniku Đakovačke biskupije objave informacije o radovima na katedrali i za njih pristiglim novčanim prilozima. Na to je Anaković odgovorio da su planirali u službenom biskupijskom glasilu objaviti da je pri-

25 NAĐ-BK, 900/1964, 17. travnja 1964., 1152/1964, 3. lipnja 1964.

26 NAĐ-BK, 300/1965, 18. siječnja 1965. 
mljena pomoć od države i da će to svakako učiniti kad počnu s radovima na katedrali. ${ }^{27}$ To je i učinjeno već idućega mjeseca, kad je u Vjesniku Đakovačke biskupije objavljena informacija o proteklim i planiranim radovima na katedrali. Pritom je istaknuto da je Odbor za obnovu katedrale primio i znatnu financijsku pomoć od državnih vlasti - 1,7 milijuna dinara od Upravnoga odbora za unapređivanje kulturnih djelatnosti pri Sekretarijatu za kulturu Socijalističke Republike Hrvatske, 2 milijuna dinara od Komisije za vjerske poslove Socijalističke Republike Hrvatske, 2 milijuna dinara u obliku kredita na 20 godina uz kamatu od 1\% od Općinskoga fonda za stambenu izgradnju u Đakovu te građevni materijal u vrijednosti od milijun dinara od Općinskoga odbora za obnovu šteta nastalih od potresa. ${ }^{28}$

Konačna obnova đakovačke katedrale započela je krajem kolovoza 1965. postavljanjem 54-metarske građevinske skele na lijevi toranj. Budući da je katedrala od 1962. bila upisana u Registar nepokretnih spomenika kulture kotara Osijek, nikakvi poslovi obnove nisu mogli biti izvršeni bez prethodnoga odobrenja Zavoda za zaštitu spomenika kulture u Osijeku i ishođenja građevinske dozvole. Elaborat za obavljanje radova na popravku katedrale izradio je Konzervatorski zavod iz Zagreba, na osnovi kojega je Zavod za zaštitu spomenika kulture u Osijeku odobrio početak radova. Glavni dio radova na katedrali odnosio se na ponovno postavljanje kamenoga ljiljana na vrh lijevoga tornja, popravak ostalih oštećenih kamenih dijelova te sve potrebne ciglarske i limarske radove. Trajanje radova bilo je nemoguće predvidjeti jer su vanjski radovi na katedrali uvelike ovisili i o vremenskim prilikama, a po završet$\mathrm{ku}$ radova na lijevom tornju bilo je potrebno demontirati skelu i ponovno ju montirati na desni toranj. ${ }^{29}$

Dok su trajali navedeni radovi, biskup Bäuerlein i Odbor za obnovu katedrale nastojali su od državnih vlasti ishoditi oslobođenje od plaćanja poreza na dohodak i carine na opremu za katedralu, točnije razglasni uređaj i električni satni mehanizam. U tu se svrhu Bäuerlein 19. kolovoza 1965. predstavkom obratio Saveznom sekretarijatu za financije. Ističući kulturno i povijesno značenje đakovačke katedrale, navodi da Biskupski ordinarijat poduzima sve što je potrebno da bi se katedrala temeljito obnovila i bila spremna za svečanu 100. obljetnicu početka gradnje. Kaže da je Ordinarijat novi satni mehanizam naručio od poznate tvrtke „Philipp Hörz” iz Ulma, koja je obećala uz pomoć pojedinih karitativnih ustanova u Zapadnoj Njemačkoj satove izraditi i postaviti besplatno. Razglasni uređaji naručeni su od tvrtke za elektroakustiku „Karl Strässer” iz Stuttgarta te će i njih, kao i satove, Đakovačka biskupija dobiti besplatno. Stoga Bäuerlein moli da se za uvoz tih uređaja Biskupski ordinarijat oslobodi plaćanja poreza i carine, uz napomenu: „Štrosmajerova je

27 AKMADŽA, Crkva i država, sv. IV: 1965. - 1968., 68.

28 Vjesnik biskupije Đakovačke (Đakovo), ožujak 1965., 42.

29 NAĐ-BK, 1889/1964, 22. svibnja 1964.; HR-DAOS-1094-OK SKH DJ, kut. 15, Okružnice i obavijesti Biskupskog ordinarijata u Đakovu, O-VI-1965, 164; „Ruža opet na vrhu lijevog tornja”, Đakovački gospodarski list, 10. 9. 1965., 4. 
katedrala u Djakovu radi svoje monumentalnosti, te umjetničke i historijske vrijednosti stavljena pod zaštitu države na temelju Zakona o zaštiti spomenika kulture. A Zakon o zaštiti spomenika kulture u svom čl. 16 kaže doslovno ovo: 'Imaoci spomenika uživaju u pogledu spomenika porezne, carinske i druge olakšice predvidjene posebnim propisima."” Na kraju predstavke dodaje da su satovi na katedrali jedini javni satovi u Đakovu i služe za opće svrhe grada i građana te da su i od Skupštine općine Đakovo, koja je Ordinarijatu dala i određena novčana sredstva za satove, zamoljeni da oni budu što prije nabavljeni i postavljeni. Tu je predstavku biskup Bäuerlein poslao Komisiji za vjerska pitanja u Zagrebu i Saveznoj komisiji za vjerska pitanja u Beogradu uz molbu da se založe kod Sekretarijata za financije za pozitivno rješenje njihova zahtjeva. ${ }^{30}$

Nastojeći ubrzati rješenje biskupove predstavke jer je iz Carinarnice u Osijeku stigla obavijest da je razglasni uređaj već stigao, član Odbora za obnovu katedrale Rudolf Šverer posjetio je 7. rujna 1965. Saveznu komisiju za vjerska pitanja u Beogradu. Ondje je razgovarao s pomoćnikom predsjednika Zlatkom Fridom, a na pitanje postoji li mogućnost za oslobađanje od plaćanja carine na dobivene uređaje Frid je odgovorio da za to ne postoji nikakva zakonska mogućnost. Umjesto toga predložio mu je da se Biskupija obrati Komisiji za vjerska pitanja u Zagrebu posebnom molbom za novčanu pomoć u visini plaćenoga iznosa za carinu s obzirom na to da je za njihovu nabavu zainteresirana i Skupština općine Đakovo. ${ }^{31}$

Odbor za obnovu katedrale postupio je prema preporuci i 10. rujna 1965. uputio predstavku Komisiji za vjerska pitanja u Zagrebu. U njoj je, kao i u većini sličnih predstavki, iznesen kratki historijat đakovačke katedrale, razmjeri štete koju je pretrpjela u Drugom svjetskom ratu i uslijed potresa, kao i važnost uređaja koji se nabavljaju. Posebno je istaknuta potreba za razglasnim uređajem, za koji navode da će biti od velike pomoći tijekom turističkih posjeta katedrali jer bi se preko njega turistima na raznim jezicima opisivala katedrala i njezina povijest. Ističe se da su razglasni uređaji već stigli i da ih je Biskupski ordinarijat preuzeo da bi se izbjeglo plaćanje ležarine te je plaćena carina u iznosu od 1,7 milijuna dinara. S obzirom na to da se očekivalo da bi iznos carine za satove mogao biti približno jednak, Odbor na kraju predstavke moli novčanu pomoć u visini od 4 milijuna dinara za podmirivanje svih carinskih troškova. ${ }^{32}$

Kako tijekom idućih deset dana nije bilo nikakva odgovora na predstavku, Rudolf Šverer otputovao je u Zagreb i nenajavljeno posjetio Komisiju za vjerska pitanja. Zbog odsutnosti tajnika Komisije Ivana Lozića, kod kojega je Šverer tražio prijam, razgovor je vodio savjetnik Komisije Ivan Ceranić. Šverer je Ceranića uputio u sve što su dotad poduzeli u svezi s podmirivanjem troškova carine, uz napomenu da im je jako bitno da dobiju traženu novčanu pomoć jer

\footnotetext{
30 AKMADŽA, Crkva i država, sv. IV: 1965. - 1968., 817-819.

31 Isto, 819-820.

32 Isto, $820-822$.
} 
je razglasni uređaj već stigao, a satovi bi trebali stići početkom 1966. godine. Ceranić je na to odgovorio da su Komisija i još neke državne institucije već u nekoliko navrata financijski pomogle u popravku katedrale, cijeneći njezinu kulturno-povijesnu važnost. Što se tiče zahtjeva za još 4 milijuna dinara, ističe da se sada svugdje provodi proračunska štednja, da će se to morati rješavati u suradnji sa Saveznom komisijom te da nije siguran da će se moći odobriti čitava svota, nego da će i Biskupija morati financijski u tome sudjelovati. Šverer je na kraju razgovora još jednom zamolio da se to pozitivno riješi jer su sav drugi građevni materijal već nabavili, kao i montažne skele, koje su stajale oko 10 milijuna dinara, na što je Ceranić odgovorio da će biti obaviješteni o rješenju zahtjeva nakon što ga Komisija razmotri. ${ }^{33}$

Postavljanje razglasnoga uređaja u katedrali završeno je 7. listopada 1965., a 1. prosinca iste godine Komisija za vjerska pitanja u Zagrebu odobrila je Biskupskom ordinarijatu u Đakovu iznos od milijun dinara. Informaciju o odobrenju iznosa predstavnici Odbora za obnovu katedrale dobili su na sastanku s članovima Komisije za vjerska pitanja Skupštine općine Đakovo koji se odrŽao 9. prosinca 1965. godine. Predsjednik Općinske vjerske komisije Mirko Brođanac izvijestio je prisutne o donaciji uz napomenu da će im naknadno biti dodijeljen još dio traženih novčanih sredstava, ali da im se ipak neće moći dodijeliti cijeli traženi iznos od 4 milijuna. Novac je na račun Biskupskoga ordinarijata uplaćen 15. siječnja 1966. te je istoga dana kanonik Šverer uputio dopis zahvale Komisiji za vjerska pitanja u Zagrebu, uz molbu da im se i tijekom 1966. odobri izvjesna pomoć. Usto je naveo da su trenutačno u tijeku kiparsko-klesarski radovi u unutrašnjosti katedrale te da će se s vanjskim radovima nastaviti u proljeće, kad vremenske prilike budu povoljnije. ${ }^{34}$

Najzahtjevniji dio vanjskih radova na katedrali, koji se odnosio na popravak porušenoga sjevernog tornja i ponovno postavljanje kamenoga ljiljana, bio je gotov u lipnju 1966. godine. Preostalo je još bilo postavljanje satnoga mehanizma, koji je istoga mjeseca bio poslan iz Ulma i čekao se njegov dolazak. Time je ponovno pokrenuto pitanje plaćanja carine na dobivene satove, pa je biskup Bäuerlein 13. kolovoza iste godine uputio predstavku Sekretarijatu za financije u Zagrebu tražeći oslobođenje od plaćanja. Ponavljajući argumente koji su se navodili i u svim prijašnjim predstavkama, Bäuerlein dodaje da su „duboko uvjereni, da će ova naša molba biti povoljno riješena, pa će i to rješenje mnogo doprinijeti provođenju u život Beogradskog Protokola ${ }^{35} \mathrm{o}$

\footnotetext{
$33 \quad$ Isto, 822-833.

34 NAĐ-BK, 300/1965, 8. listopada 1965.; AKMADŽA, Crkva i država, sv. IV: 1965. - 1968. $182-183,823$.

35 Beogradski protokol potpisan je 25. lipnja 1966. nakon višegodišnjih pregovora predstavnika Vlade SFRJ i predstavnika Svete Stolice s ciljem sređivanja odnosa između komunističkih vlasti i Katoličke crkve u Jugoslaviji. Tim su protokolom ponovno uspostavljeni poluslužbeni diplomatski odnosi između Jugoslavije i Svete Stolice, koji su bili prekinuti krajem 1952. godine. Protokolom je, među ostalim, utvrđeno da Vlada SFRJ jamči Katoličkoj crkvi slobodno obavljanje vjerskih poslova i obreda te poštovanje slobode savjesti i vjeroispovijesti svim građanima, a s druge strane Sveta Stolica potvrdila je načelni stav da se djelatnost kato-
} 
sređivanju odnosa Katoličke crkve i SFR Jugoslavije od 25. lipnja 1966.” Nadalje u molbi ističe da električne mehanizme za satove na tornjevima crkava ne izrađuje nijedna tvornica u Jugoslaviji te da prema tome njihovim uvozom iz inozemstva nije ugrožena domaća industrija. Dalje iz predstavke doznajemo da je satni mehanizam već stigao u Đakovo u 13 velikih paketa $\mathrm{i}$ da im je $\mathrm{u}$ dogovoru s Carinarnicom u Osijeku odobreno izvancarinsko skladištenje u samoj katedrali da ne bi morali plaćati visoke troškove skladištenja i ležarinu. Međutim, satovi se nisu smjeli raspakirati i postaviti prije negoli se riješi pitanje carine. Bäuerlein navodi i primjer crkve sv. Antuna u Beogradu, koja je prije kratkoga vremena oslobođena plaćanja poreza na uvezene orgulje. Moleći pozitivno rješenje, na kraju predstavke Bäuerlein ističe: „Svečanu proslavu 100-godišnjice naše katedrale planirali smo za 2. X. o. g., pa nam je mnogo stalo do toga da do toga vremena budu satovi postavljeni na tornjeve, jer na tu proslavu smo pozvali, pored najviših predstavnika saveznih, republičkih, kotarskih i općinskih organa narodne vlasti, također i predstavnike Internacionalnog Karitasa iz Rima, naše dobrotvore. Bilo bi jako nezgodno da do tog vremena ne budu i satovi postavljeni. Tim više, što su monteri za postavljanje satova spremni da odmah započnu posao montaže, čim povoljno rješimo pitanje carine." Jedan primjerak te predstavke uz popratni dopis kanonik Šverer osobno je uručio i savjetniku Komisije za vjerska pitanja u Zagrebu Branku Kosanoviću, koji mu je obećao preporuku Komisije, a zahtjev Biskupskoga ordinarijata podržala je i Komisija za vjerska pitanja Skupštine općine Đakovo. ${ }^{36}$

Iako iz dostupnoga arhivskoga gradiva nije poznat konkretan odgovor Sekretarijata za financije, s obzirom na navedene preporuke pretpostavlja se da je zahtjev riješen pozitivno. Osim toga, u različitim izvještajima o svečanoj proslavi koja je održana početkom listopada ističe se da je uspješno dovršena obnova đakovačke katedrale. Dodatni radovi u unutrašnjosti katedrale, uglavnom umjetničkoga karaktera, nastavljeni su i tijekom 1967. godine. Naime, naručeni Križni put akademskoga kipara Luje Lozice nije uspio biti završen za proslavu 100. obljetnice te je postavljen i posvećen na blagdan sv. Josipa 19. ožujka 1968. godine. Time su završeni i posljednji radovi na obnovi i uređenju katedrale, a Odbor za obnovu katedrale raspušten je 28. veljače 1969. odlukom biskupa Bäuerleina. ${ }^{37}$

\section{Zaključak}

Potres je 1964. učinio od širega područja Slavonije veliko gradilište. Zbog opsega materijalne štete, ali i slaboga imovinskog stanja stanovništva, pogođeno područje obnavljalo se nekoliko idućih godina. Velike štete pretrpjeli su

ličkih svećenika treba odvijati u vjerskim i crkvenim okvirima te da u skladu s tim ne smiju zlorabiti svoje vjerske i crkvene dužnosti u svrhe koje bi imale političku narav.

36 AKMADŽA, Crkva i država, sv. IV: 1965. - 1968., 783, 824-826.

37 NAĐ-BK, Obavijesti i okružnice Biskupskog ordinarijata u Đakovu, O-I-1969, str. 45; ĆURIĆ, Križni put u Strossmayerovoj katedrali, 6. 
i vjerski objekti u vlasništvu Katoličke crkve, pri čemu su najveće štete zabilježene u zapadnom dijelu Đakovačke i Srijemske biskupije. Ukupna šteta na njima procjenjivala se na 300 milijuna dinara. Veliku štetu, procijenjenu na 12 milijuna dinara, pretrpjela je i katedrala sv. Petra u Đakovu, koja je upravo početkom šezdesetih godina započela s popravljanjem oštećenja nastalih još u vrijeme Drugoga svjetskog rata. Zbog nedostatka materijalnih sredstava, ali i zategnutih odnosa Crkve i države, zbog kojih Katolička crkva nije mogla računati na veću financijsku potporu države, obnovi se nije moglo pristupiti ranije. Tek započetu obnovu potres i novonastale štete odgodili su i produljili za više od dvije godine. U zalaganju za obnovu katedrale ponajviše se istaknuo tadašnji biskup Stjepan Bäuerlein kao glavni inicijator te Odbor za obnovu katedrale na čelu s mons. Josipom Sokolom i ostalim članovima Stolnoga kaptola. Oni su svojim trudom, radom i kontaktima s predstavnicima vlasti te uz pomoć domaćih i inozemnih karitativnih ustanova omogućili da se radovi na katedrali nakon niza godina uspješno privedu kraju. Na kraju, ne treba zaboraviti ni brojne donacije vjernika, svećenika i biskupa iz zemlje i inozemstva koje su nakon potresa pristizale u Đakovo i uvelike doprinijele da tamošnja stolna crkva dobije izgled kakav zaslužuje jedna od najreprezentativnijih sakralnih građevina XIX. stoljeća.

\section{Arhivski izvori}

HR-DAOS-64-SKO: Hrvatska, Državni arhiv u Osijeku, fond 64, Skupština kotara Osijek 1945. - 1967.

HR-DAOS-1094-OK SKH DJ: Hrvatska, Državni arhiv u Osijeku, fond 1094, Općinski komitet Saveza komunista Hrvatske Đakovo.

NAĐ-BK: Nadbiskupijski arhiv Đakovo, fond Biskupske kancelarije.

\section{Tisak}

Đakovački gospodarski list (Đakovo), 1964-1965.

Glas Slavonije (Osijek), 1964, 2010.

Vjesnik biskupije Đakovačke (Đakovo), 1965.

\section{Literatura}

AKMADŽA, Miroslav. Crkva i država, sv. III: 1961. - 1964. Dopisivanje i razgovori između predstavnika Katoličke crkve i komunističke državne vlasti u Jugoslaviji. Zagreb; Slavonski Brod: Društvo za povjesnicu Zagrebačke nadbiskupije "Tkalčić”; Hrvatski institut za povijest, Podružnica za povijest Slavonije, Srijema i Baranje, 2012.

AKMADŽA, Miroslav. Crkva i država, sv. IV: 1965. - 1968. Dopisivanje i razgovori između predstavnika Katoličke crkve i komunističke državne vlasti u Jugoslaviji. Zagreb; Slavonski Brod: Društvo za povjesnicu Zagrebačke nadbiskupije "Tkalčić”; Hrvatski institut za povijest, Podružnica za povijest Slavonije, Srijema i Baranje, 2017. 
BOŽIĆ-DRLJAČA, Vesna. „Pregled uprave na području Državnog arhiva u Osijeku 1947. - 1992." Glasnik arhiva Slavonije i Baranje (2001), br. 6: 321364.

ĆURIĆ, Mirko. Križni put u Strossmayerovoj katedrali akademskog kipara Luje Lozice. Đakovo: Đakovački kulturni krug, 2017.

DAMJANOVIĆ, Dragan. Đakovačka katedrala. Zagreb: Matica hrvatska, 2009.

DAMJANOVIĆ, Dragan. „Đakovačka katedrala”. Doktorska disertacija, Sveučilište u Zagrebu, 2007.

HRSTIĆ, Ivan. „Zbivanja na Makarskom primorju tijekom i nakon potresa 1962. godine”. U: Makarsko primorje danas. Makarsko primorje od kraja Drugog svjetskog rata do 2011., ur. Marko Mustapić i Ivan Hrstić. Zagreb; Makarska: Institut društvenih znanosti Ivo Pilar; Grad Makarska, 2012, 277-296.

JOSIPOVIĆ BATOREK, Slađana. „Potres u Đakovštini 1964. godine”. Zbornik Muzeja Đakovštine (2013), br. 1: 179-196.

JOSIPOVIĆ BATOREK, Slađana. Sukob i(li) suradnja. Crkveno-državni odnosi u Đakovačkoj i Srijemskoj biskupiji od 1945. do 1959. Osijek: Oksimoron; Matica Hrvatska, Ogranak, 2020.

MUSTAPIĆ, Marko; KARAJIĆ, Nenad. „Prirodne katastrofe kao čimbenici modernizacije hrvatskog društva: primjer potresa 1962. godine na Makarskom primorju”. U: Makarsko primorje danas. Makarsko primorje od kraja Drugog svjetskog rata do 2011., ur. Marko Mustapić i Ivan Hrstić. Zagreb; Makarska: Institut društvenih znanosti Ivo Pilar; Grad Makarska, 2012, 297-317.

\section{Internet}

Kunalipa - Hrvatski numizmatički portal. Pristup ostvaren 30. 6. 2021. http://www.kunalipa.com/katalog/tecaj/yu-dinar-1945-1965.php; http://www. kunalipa.com/katalog/tecaj/vrijednost-dolara.php.

„Potres u Skoplju 1963.” Wikipedia. Pristup ostvaren 10. 7. 2021. https:// hr.wikipedia.org/wiki/Potres_u_Skoplju_1963.

„Zemljotresi u Banjaluci”. Pristup ostvaren 20. 6. 2021. http://www.znanje.org/i/i25/05iv02/05iv0210/zemljotresi\%20u\%20Banjaluci.htm. 


\section{The Earthquake in the Đakovo Region in 1964: The Damaging and Reconstruction of the Cathedral of St Peter in Đakovo}

Based on the accessible archival material and contemporaneous press, this paper address the consequences of the earthquake that struck the area of Slavonia in 1964 and caused great material damage. The introductory part offers an overview of the damage in the Osijek District and Đakovo Municipality, and basic data on the damage to religious buildings. The central part of the paper is devoted to the analysis of the consequences of the earthquake and the reconstruction of the Cathedral of St Peter in Đakovo. The efforts to restore the cathedral and repair the damage suffered in World War II had begun not long before the earthquake struck. The reconstruction process was led by the Cathedral Chapter, the then-established Cathedral Reconstruction Committee, and Bishop Stjepan Bäuerlein, who sent numerous petitions to the state authorities, attempting to secure the financial aid necessary for the reconstruction efforts. Through their diligence, work, and contacts with representatives of the government, and with the help of domestic and foreign charity institutions, they made it possible for the reconstruction work on the cathedral to be successfully completed years later. The numerous donations of believers, priests, and bishops from the country and abroad must also be mentioned. They played an important role in enabling the Cathedral in Đakovo to achieve an appearance worthy of one of the most representative sacral buildings of the $19^{\text {th }}$ century.

Key words: earthquake; Đakovo region; 1964; Diocese of Đakovo and Srijem; Cathedral of St Peter in Đakovo; Cathedral Reconstruction Committee; Bishop Stjepan Bäuerlein 